\title{
Job quality and inequality The unequal world of work in the UK, 1986-2012
}

Job quality has become a prominent issue in recent years - and with good reason, say Francis Green, Alan Felstead and Duncan Gallie. Their findings on inequality and job quality and how they have changed illuminate the true state of Britain's labour market, and make clear the need for changes in policy to improve working lives.

Following the slow decline in headline unemployment since the Great Recession, the issue of the quality of jobs in Britain has come increasingly to the fore. Average wages have fallen in real terms since 2008. With declining benefits, families become yet more dependent on their pay packets for meeting living costs, and even the Conservatives have felt the need to embrace the 'living wage' strategy to try to redress the balance for the poorest households. But beyond wages themselves, the British workplace is, for many, a place of stress, with 9.9 million days continuing to be lost for this reason every year. ${ }^{1}$ It is not only that wages have been falling but other elements of job quality have seemingly also deteriorated, with the spread of high work intensity and low workplace autonomy.

Just looking at the averages also misses the changing inequalities that have beset workplaces. Britain's wage distribution now glories in the distinction of being the most unequal in Europe. To many, the future of work also appears distinctly insecure, with threats of replacement or downgrading through automation and ongoing international competition through outsourcing each fed by a neoliberal ideology of the workplace that remains unscarred by the macroeconomic crisis. The prospect of Brexit should also give most ordinary workers great cause for concern: although deregulation appears not to have figured in current negotiations, the opportunity to repeal worker-protective legislation previously mandated through European directives remains a significant argument for businesses and right-wing politicians in the 'out' campaign.

To understand the state of job quality in Britain today, it is important to have a picture of how we got to where we are. Both political and technological factors have been important. The neoliberal era for work in Britain began in the 1980s with employment relations' own 'big bang' - a co-ordinated programme of deregulation, privatisation and the weakening of trade unions, each of which contributed to the longterm decline in the share of wages. Neoliberalism in work was held in 
check during the New Labour era by the favourable reception given to the European directives, leading to important regulatory constraints on working hours, holidays, part-time and fixed-term worker's conditions, company-level participation and certain 'rights to request' flexible working hours. Since the demise of the Labour government in 2010, while the actual changes made under the Coalition government were comparatively minor, the current anti-trade-union legislation and the prospect of Brexit are very real concerns. Meanwhile, these political drivers have been embedded in an ongoing process of organisational and technological change, embracing a so-called 'fourth Industrial Revolution' coming in the near future through artificial intelligence and automation, which has the potential to drive greater inequality (a potential that employers are seizing upon).

\section{DEFINING AND EXPLORING 'JOB QUALITY'}

Changes in Britain's job quality over the last quarter-century have been studied by a team of labour sociologists and economists in our recent book, Unequal Britain at Work. ${ }^{2}$ To avoid a too-rosy perspective on how things used to be at work, we used the method of comparing successive high-quality, nationally-representative surveys. The Skills and Employment Surveys, as this series has come to be known, began in 1986 and were repeated roughly every five years using many common questions, with the most recent being carried out in 2012. We used their data to validly compare over time the jobs held by 20-60-year-olds. We also used the European Working Conditions Surveys, which cover the period 1990-2015.

Under our definition, 'job quality' - those characteristics of jobs that significantly contribute towards people's needs from work - has four aspects: wages; prospects and insecurity; intrinsic quality; and the quality of work time. Our study, which focussed mainly on the first three of these aspects, revealed striking advances in some regards over this period, including some that are often overlooked in a haze of nostalgia. At the same time, however, job quality grew worse in other respects. ${ }^{3}$

On the positive side, real wages increased steadily on average until the late-2000s, though they then regressed to around the level they attained in the early 2000s. Some other aspects of job quality also improved over the quarter-century, if only incrementally. On average, jobs became more skilled. The physical environment improved, with fewer accidents at work and fewer people working in physically demanding conditions. From the mid-1990s onwards, working hours improved, with fewer people especially men - working long hours (that is, more than 48 per week), and the achievement of near-universal rights to paid holiday which benefited more than a million women.

However, set against these prizes of affluence were some major declines in intrinsic job quality. In particular, through the 1990s there were striking reductions in the extent of worker task discretion - a decline

"Striking advances
in job quality
have been made
over this period,
including some
that are often
overlooked in a
haze of nostalgia.
At the same time,
however, job
quality grew worse
in other respects."

"Striking advances in job quality have been made over this period, including some that are often overlooked in a haze of nostalgia. At the same time, however, job quality grew worse 
in job quality that has not been rectified since. Meanwhile, in the first half of the 1990s there was a major intensification of work in Britain's workplaces; for several years after that there was little change, but work intensity resumed its rise during the 2000 s. By 2012 , to cite just one indicator among several, 40 per cent of workers strongly agreed that their work involved working at very high speeds at least three-quarters of the time if not more - compared with just 23 per cent in 1992. As work psychologists have known for some time, low autonomy and high work intensity is an especially toxic combination, with consequences for work stress and lost work-days. Work intensification may also have contributed to the rising levels of male economic inactivity that characterised the 1990s.

The recent period of recession and slow growth has also seen a broadening of insecurities, as more workers came to fear the loss of their job and unemployment, and more became anxious about arbitrary treatment at work. People's anxieties are now quite wide-ranging. In 2012, many workers feared that their job would become less skilled or less interesting, or that they would lose pay or autonomy. We also found that 23 per cent of employees were 'very anxious' about at least one of these factors. ${ }^{4}$

\section{INEQUALITIES IN JOB OUALITY}

Over time there have also been some striking changes in the inequality of job quality - most notably in terms of wages, which polarised markedly across classes over the period 1986-2012. ${ }^{5}$ The consequence was that, at the 10th percentile, wages were barely higher at their pre-recessionary peak in the 2000s than they had been in 1990, and by 2012 were down to the level of 1979 . Since the late-1990s, pay inequality was stabilised in the lower half of the distribution, but pay was stretched greatly at the top end. The gender gap at work persisted over this period, though it appears to have fallen somewhat: after allowing for differences in age, skill-use and occupation, the pay gap fell from 14.8 per cent in 1997 to 7.5 per cent in 2012. Part of what lay behind this change was a process of occupational upgrading for women, in contrast with men for whom employment has become increasingly polarised between high- and lowskilled jobs. ${ }^{6}$ Increases in job quality were found, in particular, for women working longer-hours part-time, and there has been some convergence in recent years between the job-qualities of workers on temporary and permanent contracts. ${ }^{7}$

An important area of differentiation is within the category of self-employed workers. These workers have, in many ways, a better intrinsic job quality than employees, and their job quality improved relative to employees up until 2006. After that, however, the job quality of self-employed workers fell

"The recent period
of recession and
slow growth
has also seen a
broadening of
insecurities, as
more workers
came to fear
the loss of
their job and
unemployment."

"The recent period slow growth has also seen a broadening of insecurities, as more workers came to fear their job and

4 Gallie D, Felstead A, Green F and Inanc H (2016 forthcoming) 'The Hidden Face of Job Insecurity', Work, Employment and Society.

5 Gallie D (2015) 'Class Inequality at Work: Trends to Polarization?', in Felstead et al 2015

6 Lindley J (2015) 'Gender Differences in Job Quality', in Felstead et al 2015.

7 Warren T and Lyonette C (2015) 'The Quality of Part-Time Work', and Inanc H (2015) 'Temporary Work and Job Quality', both in Felstead et al 2015. 
in important respects. Much of the rise in self-employment between 2006 and 2012 was among sole traders and those with recent experience of unemployment - often described as 'bad' self-employment, insofar as it was taken up as an alternative to life as an employee when jobs were scarce. ${ }^{8}$

\section{UNIONS AND THE PRIVATE/PUBLIC SECTOR DIVIDE}

How did the influence of trade unions on job quality fare over the period we examined? Unsurprisingly, given the long-term decline in union membership and recognition since the 1980s, there has been a marked decline in their ability to affect wages. A trade union's impact on wages, relative to comparable work in non-union workplaces, declined in all sectors, and in the private sector was virtually nil in the 2000s. ${ }^{9}$ Moreover, unionised workplaces appear to have borne a disproportionate share of the work intensification and insecurity that occurred between 1986 and 2012. Nevertheless, even at the end of that period unions appear still to have some equalising impact on wages in the places where they are still present, and are still perceived by workers as making a difference in terms of work organisation. One significant conclusion is that unionised workplaces have increasingly transformed into learning environments. This outcome reflects the strategy adopted by many unions since the 1990s to embrace learning in order to increase work security for lowskilled employees.

The broad range of job quality indicators used in our study were also important for understanding a perennial topic of public discourse: the differences between private- and public-sector jobs. ${ }^{10}$ Popular rhetoric has it that public sector workers fare better, but most studies fail to take into account the fact that the jobs in the two sectors are typically very different. For example, public sector work, while requiring generally higher levels of education, tends to be more intense - and in recent years has become more insecure - than private sector work. When these differences are taken into account, the pay differences between the two sectors are much smaller, leaving only a minor advantage to women from working in the public sector, and none for men. Overall, these findings give an endorsement to the judgements of public pay review bodies, which are charged with ensuring equity between private and public sectors in order to ensure an efficient labour market.

\section{IMPLICATIONS FOR JOB OUALITY POLICY}

There are no indications that, in the wake of the recession, the average British employer is reorganising workplaces in ways that will bring about significant improvements in job quality. There are, of course, many exceptions. High-involvement work practices, for example, are often (though not always) found to be beneficial for workers, but too few employers are adopting this approach to work organisation,

"Popular rhetoric
has it that public
sector workers
fare better, but
most studies
fail to take into
account the fact
that the jobs in
the two sectors
are typically
very different."

8 Baumberg B and Meager N (2015) 'Job Quality and the Self-Employed: Is It Still Better to Work for Yourself?', in Felstead et al 2015.

9 Bryson A and Green F (2015) ‘Unions and Job Quality', in Felstead et al 2015.

10 Blackaby D, Felstead A, Jones M, Makepeace G, Murphy P and Wass V (2015) 'Is the Public Sector Pay Advantage Explained by Differences in Work Quality?', in Felstead et al 2015. 
and there is no sign of them expanding greatly. ${ }^{11}$ The case for policy interventions to improve job quality is therefore strong, even if it presents many challenges that are exacerbated by neoliberal thinking's current domination of policymaking. In addition to wages, Britain's low levels of task discretion, ongoing work intensification, and the broadening of job insecurity are among the key problems that policymakers should be addressing.

Notwithstanding Britain's high wage inequality, in many respects job quality in Britain is similar to that of other advanced European economies, and better on the whole than in the poorer countries of eastern and southern Europe. Yet in terms of job autonomy, British workplaces compare quite poorly. There is much to learn from other countries in this regard - most notably the Nordic countries, where both policy and practice have done more to promote high intrinsic job quality. We review a number of practical ideas in the final chapter of our book. ${ }^{12}$ One proposal is that there should be a centre for advice and research on intrinsic job quality, the purpose of which would be to lead and encourage much-needed changes in British businesses. Its remit could include engaging with and advising businesses, and the government itself, in the area of job design. In addition, it could promote and evaluate job quality policies. An institutional presence would signal the policy importance of tackling the problems of low job-quality. Proposals that we support include: a strengthening of information and consultation of employees (ICE) regulations in order to increase the level of employee voice in workplace organisation; ensuring enforcement of the Health and Safety Commission's management standards; providing training for GPs in the effective implementation of 'fit notes' for work; placing job quality conditions on public procurement; and an enhancement of transparency through a broadening of the Investors in People system to incorporate standards on job quality and require job quality reports to be included in company reporting.

Good jobs are important contributors to health and wellbeing; conversely, poor job quality piles costs on to the health system and the economy. Yet with the macroeconomic outlook quite bleak, and a real risk of the removal of proper labour market regulations should Britain withdraw from Europe, it is as important as ever to recognise and build the evidence-based case for better job design and improved job quality.

\section{Alan Felstead is a research professor at the Cardiff School of Social Sciences, Cardiff University. Duncan Gallie is professor of sociology and emeritus fellow of Nuffield College, University of Oxford. Francis Green is professor of work and education economics at University College London.}

\section{"In many respects job quality in Britain is similar to that of other advanced European economies. Yet in terms of job autonomy, British workplaces compare quite poorly."}

